Pediatr. Res. 15: 112-114 (1981)

brush border membrane enzyme activities

D-glucose

glycine intestine phospholipids undernutrition

\title{
Intestinal Brush Border Membrane Structure and Function: Effect of Early Postnatal Undernutrition
}

\author{
R. M. PATHAK, A. MAHMOOD, ${ }^{(32)}$ P. K. DUDEJA, AND D. SUBRAHMANYAM \\ Departments of Biochemistry and Gastroenterology, Postgraduate Institute of Medical Education and Research. \\ Chandigarh 160012, India
}

\begin{abstract}
Summary
The effect of undernutrition during suckling has been investigated on the brush border enzymes and the intestinal uptake of $D$ glucose and glycine in rats at weaning. The brush border sucrase and alkaline phosphatase activities were drastically reduced, but lactase and leucine aminopeptidase levels were significantly elevated in the intestine of nutritionally deprived pups compared to controls. The uptake of D-glucose and glycine in undernourished rats was also augmented. The chemical composition of the brush border membrane analyzed in nutritionally deficient animals revealed an enhancement of the membrane protein, sialic acid, cholesterol, and phospholipids compared to the control group. [U- $\left.{ }^{14} \mathrm{C}\right] \mathrm{D}-$ Glucose incorporation into lipid constituents of the membrane suggested that the observed enhancement of the membrane lipids is the result of an increased synthesis in response to undernutrition.
\end{abstract}

\section{Speculation}

It may be surmised that undernutrition induced postnatally influences the structural and functional organization of the brush border membrane because of delayed maturation of the epithelial tissue. Endocrine disturbances in undernutrition may be implicated to the observed phenomenon.

Malnutrition severely affects the growth and development of the intestinal tissue and induces an impairment of its functions (7, $21)$. Lack of adequate amounts of protein in the diet is reported to produce morphologic abberations of the intestinal epithelium $(6,20)$. Increase in the activities of disaccharidases and a decrease in the levels of peptidase activity in protein-calorie malnutrition has been observed (26). Alterations in the permeability characteristics of the enterocytes have also been documented in undernutrition $(1,27)$. Malnourished infants frequently suffer from various intestinal disorders (25), the precise molecular basis of which is not clear, but infection, malabsorption, pancreatic dysfunctions, and atrophy of the intestinal mucosa have been implicated in these derangements $(3,5,6)$.

The brush border membrane (BBM) lining the surface of the epithelial cells is a mosaic of the structural and functional proteins intercalated in the lipid bilayer and is the primary site responsible for the terminal stages of digestion and absorption (10). To our knowledge, there are no reports on the effect of nutritional deprivation on the chemical architecture of the BBM; therefore, the present studies were undertaken to investigate the structural and functional characteristics of the BBM in undernutrition.

\section{MATERIALS AND METHODS}

Albino rats (Wistar strain) were used in these experiments. Undernutrition (UN) was induced by increasing the litter size as described by Winick and Noble (29). There were 5 to 6 pups in the control group and 16 to 18.pups in the UN group per fostering mother. Throughout the experimental period, mothers were maintained on rat pellet diet (Hindustan Lever Ltd., Bombay, India) and had free access to water. At the time of sacrifice, the average body weight of the animals in the control and experimental groups was $25.5 \pm 0.6$ and $16.6 \pm 1.0$ (mean \pm S.D.), respectively.

\section{ISOLATION OF THE BRUSH BORDER MEMBRANES}

On day 21 , overnight fasted pups were sacrificed under ether anesthesia. Starting from the ligament of Tretiz, an approximately $20 \mathrm{~cm}$ portion of the jejunum was removed, immediately flushed with cold saline, and everted. BBM were isolated and purified following the method of Schmitz et al. (24). Membranes obtained by this procedure are essentially free from other subcellular contaminants such as DNA, mitochondria, microsomes, and basolateral membranes. The membranes were suspended in $50 \mathrm{mM}$ sodium maleate buffer, $\mathrm{pH} 6.5$, and exhibited 20- to 23-fold enrichment of the brush border sucrase (BBS) over the crude homogenate with 75 to $80 \%$ recovery.

\section{EXTRACTION OF LIPIDS AND CHEMICAL ANALYSIS}

Membrane lipids were extracted in chloroform:methanol (2:1 $v / v$ ) as described by Folch et al. (12). Separation, identification, and quantitation of various lipid fractions were carried out as described elsewhere (16). Neutral lipids were resolved on Silica Gel G-coated thin-layer glass plates using petroleum ether:solvent ether:acetic acid $(90: 10: 1 \mathrm{v} / \mathrm{v})$ as the developing solvent. For the separation of phospholipid fractions, chloroform:methanol:ammonia $(65: 25: 4 \mathrm{v} / \mathrm{v})$ was the solvent system used. Various lipid fractions were identified on the thin-layer plates by simultaneously running the authentic standards. Sialic acid was estimated by the method of Warren (28). Protein was determined by Lowry's method (19) using bovine serum albumin as the standard.

\section{INTESTINAL UPTAKE STUDIES}

Intestinal uptake of D-glucose and glycine was measured as described earlier (2). Everted rings, 0.3 to $0.5 \mathrm{~cm}$, were incubated

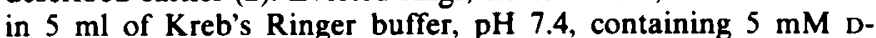
glucose or glycine with a trace of $\left[U_{-}^{14} \mathrm{C}\right] \mathrm{D}$-glucose or $\left[U_{-}{ }^{14} \mathrm{C}\right]$ glycine, respectively, for $5 \mathrm{~min}$ at $37^{\circ} \mathrm{C}$. At the end of incubation, tissues were removed, gently blotted, and weighed, and radioactivity taken up was measured by dissolving the tissues in $10 \%$ $\mathrm{KOH}$ and counted in Packard scintillation counter. After correcting for the extracellular space (2), the uptake was calculated and expressed as $\mu \mathrm{moles} / \mathrm{hr} / \mathrm{g}$ wet tissue.

\section{ENZYME ASSAYS}

A portion of the jejunum was homogenized in $50 \mathrm{mM}$ sodium maleate, $\mathrm{pH} 6.5$, and centrifuged at $1000 \times \mathrm{g}$ for $10 \mathrm{~min}$ at 0 to $4^{\circ} \mathrm{C}$. The supernatant was removed and used as such for the assays of various enzymes. Brush border lactase (BBL) and BBS were assayed by the method of Dahlqvist (11), alkaline phosphatase 
(AP) was assayed as described by Bergmeyer (4), and leucine amino peptidase (LAP) was assayed by the method of Goldbarg and Rutenberg (13).

\section{REAGENTS}

All reagents were of analytical grade. Glucostat was procured from Worthington Biochemical Corporation, Freehold, NJ. [ $U$ $\left.{ }^{14} \mathrm{C}\right] \mathrm{D}$-Glucose and $\left[U-{ }^{14} \mathrm{C}\right] \mathrm{glycine}$ were obtained from Bhabha Atomic Research Center, Bombay, India.

Statistical analysis of the data was done using Student's $t$ test.

\section{RESULTS}

The digestive and absorptive characteristics of the intestinal epithelium were assessed by measuring the brush border disaccharidases LAP and AP activities and the uptake of D-glucose and glycine in control and UN groups. These results are presented in Table 1 . The activity of BBL was considerably increased (nearly $80 \%)$ as was also the case with LAP activity $(P<0.05)$. However, BBS and AP levels were highly reduced $(P<0.001)$ in the UN group compared to the control animals. The intestinal uptake of D-glucose and glycine in nutritionally deprived pups was also significantly stimulated compared to control animals.

Inasmuch as both the digestive and absorptive functions of the enterocytes were greatly altered in pups subjected to postnatal food restrictions, it was of interest to examine whether UN also produces disturbances in the structural organization of the BBM. Thus, the protein, lipid, and sialic acid contents of the membranes isolated from control and UN animals were analyzed, and these results are presented in Table 2. Membrane protein, sialic acid, cholesterol, and phospholipid contents expressed on dry mem-

Table 1. Digestive and absorptive functions of the intestinal epithelium in undernourished pups at weaning ${ }^{1}$

\begin{tabular}{lccc}
\hline \multicolumn{1}{c}{ Function } & Control & Undernourished & $P$ \\
\hline Sucrase & $7.5 \pm 1.9^{2}$ & $2.9 \pm 0.4$ & $<0.001$ \\
Lactase & $5.1 \pm 1.2$ & $9.9 \pm 0.5$ & $<0.001$ \\
$\begin{array}{l}\text { Leucine aminopepti- } \\
\quad \text { dase }\end{array}$ & $6.1 \pm 1.2$ & $8.7 \pm 1.6$ & $<0.05$ \\
$\begin{array}{l}\text { Alkaline phospha- } \\
\quad \text { tase }\end{array}$ & $403.0 \pm 62.0$ & $183.2 \pm 45.0$ & $<0.001$ \\
$\begin{array}{l}\text { D-glucose uptake } \\
\text { Glycine uptake }\end{array}$ & $173.2 \pm 12.6$ & $211.8 \pm 31.3$ & $<0.05$ \\
\hline
\end{tabular}

' Enzyme activities are expressed as units/g tissue protein. One enzyme unit is equal to $\mu$ moles substrate hydrolyzed per min under standard assay conditions.

${ }^{2}$ Mean \pm S.D. of eight observations

${ }^{3}$ Uptake expressed as $\mu$ moles $/ \mathrm{hr} / \mathrm{g}$ wet tissue.

Table 2. Effect of undernutrition on the chemical compositon of $B B M$ of weanling rats

\begin{tabular}{lccc}
\hline Membrane fraction & $\begin{array}{c}\text { Control } \\
\text { (mg/l00 mg } \\
\text { dry mem- } \\
\text { branes) }\end{array}$ & $\begin{array}{c}\text { Undernourished } \\
\text { (mg/l00 mg } \\
\text { dry mem- } \\
\text { branes) }\end{array}$ & $P$ \\
\hline Protein & $25.7 \pm 5.2^{\prime}$ & $34.5 \pm 6.5$ & $<0.01$ \\
Sialic acid & $0.8 \pm 0.1$ & $2.1 \pm 0.1$ & $<0.001$ \\
Cholesterol & $1.2 \pm 0.2$ & $2.5 \pm 0.2$ & $<0.001$ \\
Total phospholipids & $4.7 \pm 0.2$ & $7.2 \pm 0.6$ & $<0.001$ \\
PI $^{2}+$ PS & $0.9 \pm 0.1$ & $1.2 \pm 0.1$ & $<0.01$ \\
Sph + LPE & $1.1 \pm 0.1$ & $1.7 \pm 0.2$ & $<0.01$ \\
PC & $1.5 \pm 0.1$ & $2.9 \pm 0.2$ & $<0.01$ \\
PE & $1.3 \pm 0.1$ & $1.1 \pm 0.1$ & $\mathrm{NS}$ \\
\hline
\end{tabular}

'Mean \pm S.D. of three independent observations in duplicate.

${ }^{2}$ PI, phosphatidylinositol; PS, phosphatidylserine; Sph, sphingomyelin; LPE, lysophosphatidylethanolamine; PC, phosphatidylcholine; PE, phosphatidylethanolamine; NS, not significant.
Table 3. Effect of undernutrition on in vivo $\left[U-{ }^{14} \mathrm{C}\right] \mathrm{D}$-glucose incorporation into brush border lipids in weanling rats ${ }^{1}$

\begin{tabular}{lccc}
\hline Lipid fraction & $\begin{array}{c}\text { Control } \\
\text { (cpm/100 mg } \\
\text { dry membranes) }\end{array}$ & $\begin{array}{c}\text { Undernourished } \\
\text { (cpm/100 mg } \\
\text { dry membranes) }\end{array}$ & $P$ \\
\hline Cholesterol & $302 \pm 33^{2}$ & $563 \pm 16$ & $<0.001$ \\
Total phospholipids & $(252 \pm 25)^{3}$ & $(227 \pm 30)$ & \\
& $5521 \pm 94$ & $9263 \pm 615$ & $<0.001$ \\
PI $^{4}+$ PS & $(1166 \pm 20)$ & $(1288 \pm 86)$ & \\
& $2739 \pm 70$ & $3746 \pm 283$ & $<0.01$ \\
Sph + LPE & $(3102 \pm 84)$ & $(3116 \pm 321)$ & \\
& $531 \pm 16$ & $749 \pm 96$ & $<0.01$ \\
PC & $(493 \pm 14)$ & $(428 \pm 55)$ & \\
& $891 \pm 151$ & $2066 \pm 147$ & $<0.01$ \\
PE & $(583 \pm 98)$ & $(698 \pm 49)$ & \\
& $1359 \pm 97$ & $2703 \pm 352$ & $<0.01$ \\
\hline
\end{tabular}

${ }^{1}$ Four $\mu \mathrm{Ci}$ [U $\left.-{ }^{14} \mathrm{C}\right] \mathrm{D}$-glucose were injected IP to each animal $2 \mathrm{hr}$ before sacrificing. Intestines from four to six animals were pooled and processed for the isolation of microvillus membranes as described (24).

${ }^{2}$ Mean \pm S.D. of three independent observations.

${ }^{3}$ Numbers in parentheses, specific activities as $\mathrm{cpm} / \mathrm{mg}$ specific lipid.

${ }^{4}$ PI, phosphatidylinositol; PS, phosphatidylserine; Sph, sphingomyelin; LPE, lysophosphatidylethanolamine; PC, phosphatidylcholine; PE, phosphatidylethanolamine.

brane basis were markedly elevated (80 to $250 \%$ ) in malnourished pups compared to the controls. The apparent increase in the total phospholipids of the membranes was reflected in a corresponding enhancement of the individual phospholipid fractions, viz., phosphatidylinositol, phosphatidylserine, sphingomyelin, lysophosphatidylethanolamine, and phosphatidylcholine. However, phosphatidylethanolamine levels remained unaltered in undernourished animals compared to controls.

The observed augmentation of the membrane constituents in undernutrition may result either due to stimulated synthesis or because of restricted degradation of these fractions. To distinguish between these two possible effects, we studied the incorporation of $\left[U-{ }^{14} \mathrm{C}\right] \mathrm{D}$-glucose into different lipids of the membrane in control and nutritionally deficient pups. These results are shown in Table 3. The incorporation of the radioactivity into cholesterol, total phospholipids, and individual phospholipid fractions (phosphatidylinositol + phosphatidylserine, sphingomyelin + lysophosphatidylethanolamine, phosphatidylcholine, and phosphatidylethanolamine) were significantly elevated $(P<0.01)$ in UN group compared to the control. These results suggest that intestinal epithelium of undernourished pups at weaning is potentially more active in the synthesis of lipids compared to control tissue.

\section{DISCUSSION}

The results described in this paper indicate that imposition of postnatal undernutrition profoundly alters the structural and functional organization of the microvillus membrane at weaning. These results in general are in agreement with earlier observations with adult animals that malnutrition produces pronounced abberations of the intestinal mucosa $(6,18,20)$. As shown in Table 1 , BBS and AP activities were markedly depressed, but BBL and LAP levels were substantially elevated in undernutrition. An increase in the disaccharidase levels in protein deficiency has also been described $(18,26)$.

Rubino et al. (23) have shown that the activity of BBL is quite high and BBS is almost absent during suckling, but shortly before weaning, BBL starts declining and BBS develops to the maximum. Thus, the observed decrease in BBS and an enhancement of the BBL levels in UN would imply that deprivation of food during early postnatal period delays the maturation of the intestinal tissue. Another explanation for the observed alterations in the disaccharidases activities in malnourished pups is possibly the 
hormonal imbalances, in particular, the diminished availability of thyroxine in UN (15). 3-Iodothyronine and corticosteroids are well known to induce the precocious appearance of BBS in rats (8). Thyroxine has also been implicated in the maturation of various tissues (31). The developmental pattern of AP in the intestinal tissue is similar to BBS and is also stimulated in response to cortisone administration (22).

The permeability of D-glucose and glycine was significantly elevated in UN (Table 1). Stimulation of the sugar transport system has been reported in semistarvation (14) and in proteincalorie malnutrition (1). Augmentation of tyrosine and leucine absorption in malnourished rats has been reported by Wapnir and Lifshitz (27), but they did not observe any change in the glycine uptake. An increase in the absorption of certain proteins in undernourished animals has been demonstrated by Worthington et al. (30).

The imposition of UN during suckling markedly augmented the BBM constituents (Table 2). Whether the results were expressed on wet tissue basis (not shown) or on dry membrane weight, the protein lipids and sialic acid contents were considerably elevated in membranes isolated from nutritionally deprived animals compared to controls. Such an alteration in the chemical composition of the mucosal membrane may be responsible for the intestinal derangements observed in the nutritional deficiency. Further evidence suggesting disturbances in the membrane architecture in UN is evinced by the fact that molar ratio between cholesterol:phospholipids was increased from 0.51 in control to 0.69 in the experimental group, although the cholesterol:protein or phospholipid:protein ratios remained unaffected.

The elevated levels of the membrane fractions in nutritionally deprived rats during suckling as seen in these experiments appear to be the result of an increase in the synthesis of these compounds. Such a contention is substantiated by the findings that $\left[{ }^{14} \mathrm{C}\right]$ glucose incorporation into lipids of the membrane was greatly enhanced in undernourished animals compared to controls. It may be stressed that there was no change in the specific activity of the radiolabel into lipid classes (Table 3 ) in the experimental animals compared to the control group. These results tend to suggest that UN imposed during neonatal life produces a general activation of the synthesis of these compounds. It is interesting that Kern and Hirschfield (17) have also demonstrated a preferential increase in the incorporation of $\left[{ }^{3} \mathrm{H}\right]$ leucine into proteins of jejunal mucosa in protein-deficient animals. More recently, Chauhan et al. (9) have reported an increase in the $\left[{ }^{14} \mathrm{C}\right]$ acetate incorporation into lipids of undernourished rat brain at weaning.

We believe that UN of the shorter duration, as it refers to the present studies, results in a condition of "stress" of the intestinal tissue, which induces the development of a compensatory mechanism, to overcome the strain imposed by the nonavailability of sufficient nutrients. However, the continuation of undernutrition for longer periods exhausts the nutrient reserves of the tissues to a level which may deteriorate its functional behavior, as is frequently seen in malabsorption syndromes associated with malnutrition $(7,21,25)$.

\section{REFERENCES AND NOTES}

I. Adams, J. L., and Leichter, J.: Effect of protein deficient diets with various amounts of carbohydrates on intestinal disaccharidases activities in the rat. $J$. Nutr., 103: 1716 (1973).

2. Alvarado. F., and Mahmood, A.: Cotransport of organic solutes and sodium ions in the small intestine. A general model:amino acid transport. Biochemistry. 13: 2882 (1974)
3. Barbezat, G. O., and Hansen, J. D. L.: The exocrine pancreas and protein-caloriemalnutrition. Pediatrics, 42: 77 (1968)

4. Bergmeyer, M. V. C.: Methods of Enzymatic Analysis. p. 783 (Academic Press. Inc., New York, 1963)

5. Bowie. M. D., Barbezat, G. O., and Hansen, J. D. L.: Carbohydrate absorption in malnourished children. Am. J. Clin. Nutr., 20: 89 (1967).

6. Brunser, O., Castillo, C., and Araya, M.: Fine structure of the small intestinal mucosa in infantile marasmic malnutrition. Gastroenterology, 70: 495 (1976).

7. Campos, J. V. M.. Neto, U. F., Patricio, F. R. S., Wehba, J., Carvalho, A. A., and Shinger, M.: Jejunal mucosa in marasmic children: clinical, pathological and fine structural evaluation of the protein-energy malnutrition and environmental contamination. Am. J. Clin. Nutr., 32: 1575 (1979).

8. Celano, P., Jumawan, J., Harowitz, C. Lau, H., and Koldovsky, O.: Prenatal induction of sucrase activity in rat jejunum. Biochem. J., 162: 469 (1977).

9. Chauhan, S.. Jailkani, R., and Subrahmanyam, D.: Effect of undernutrition on lipid metabolism of brain. In vivo incorporation of labelled acetate and palmitate into lipids. Nutr. Metab. 24: 43 (1980).

10. Crane, R. K.: In: C. F. Code: Hand Book of Physiology, Section Alimentary Canal, Vol. 3, p. 1323 (American Physiological Society, Washington, D. C., 1968).

11. Dahlqvist, A.: Method for assay of intestinal disaccharidases. Anal. Biochem., 7: 18 (1964).

12. Folch, J., Lees, M., and Sloane-Stanely, G. H.: A simple method for the isolation and purification of total lipids from animal tissues. J. Biol. Chem., 226: 497 (1957).

13. Goldbarg. J. A., and Rutenberg, A. M.: Colorimeteric determination of leucine amino peptidase in urine and serum of normal and patients with cancer and other diseases. Cancer (Phila.), 11: 283 (1958).

14. Hindmarsh, J. T., Kilby, D., Rose, B., and Wiseman, G.: Further studies on intestinal active transport during semistarvation. J. Physiol. (Lond.), 188: 207 (1967).

15. Ingenbleek, Y., and Beekers, C.: Thyroidal iodide clearance and radioiodide uptake in protein-calorie-malnutrition. Am. J. Clin. Nutr., 31: 408 (1978).

16. Jain, S. K.. Majumdar, S., and Subrahmanyam, D.: Effect of phenylhydrazine on the plasma lipids of albino rat. Naunyn-Schmiedeberg's Arch. Pharmacol., 298: 75 (1977).

17. Kern, J., Jr., and Hirschfield, J. S.: The incorporation of $\mathbf{H}^{\mathbf{t}}$-leucine into intestinal mucosal protein in protein deprived rats. Clin. Res., 14: 298 (1966).

18. Lifshitz, F., Hawkins, R. L., Diazbensussen, S., and Wapnir, R. A.: Absorption of carbohydrates in malnourished rats. J. Nutr., 102: 1303 (1972).

19. Lowry, O. H.. Rosebrough, N. J., Farr, A. L., and Randall, R. J.: Protein measurement with Folin phenol reagent. J. Biol. Chem., 193: 265 (1951).

20. Neutra, M. R.. Maner, J. H., and Mayoral. L. C.: Effect of protein-caloriemalnutrition on jejunal mucosa of tetracycline treated pigs. Am. J. Clin. Nutr., 27: 287 (1974).

21. Robinson, J. W. L.: Intestinal malabosrption in the experimental animal. Gut. 13: 938 (1972).

22. Ross, L.. and Goldsmith. E. D.: Histochemical studies of effects of cortisone on fetal and new born rats. Proc. Soc. Exp. Biol. Med., 90: 55 (1955).

23. Rubino, A., Zimbalatti, F., and Auricchio, S.: Intestinal disaccharidase activities in adult and suckling rats. Biochim. Biophys. Acta, 92: 305 (1964).

24. Schmitz, J. C.. Preiser, H., Maestracci, D., Ghosh, B. K., Cerdo, J. J., and Crane. R. K.: Purification of human intestinal brush border membranes. Biochim. Biophys. Acta, 323: 98 (1973).

25. Scrimshaw. N. S., Taylor, E. C., and Gordon, J. E.: Interactions of nutrition and infection. (World Health Organization. Geneva, 1968).

26. Solimano, G., Ann Burgess, E., and Levin. B.: Protein-calorie-malnutrition. Effect of deficient diets on enzyme levels of jejunal mucosa of rats. Br. J. Nutr.. 21: 55 (1967).

27. Wapnir, R. A., and Lifshitz, F.: Absorption of amino acids in malnourished rats. J. Nutr., 104: 843 (1974)

28. Warren. L.: The thiobarbituric acid assay of sialic acids. J. Biol. Chem., 234: 1971 (1959).

29. Winik, M..and Noble. A.: Cellular response in rats during malnutrition at various ages. J. Nutr., 89: 300 (1966)

30. Worthington, B. S., Boatman, E. S., and Kenny, G. E.: Intestinal absorption of intact proteins in normal and protein deficient rats. Am. J. Clin. Nutr., 27: 276 (1974).

31. Wu. B., Kikkawa. Y.. Matoyama, M. M., Kaibara, E. K., Zigas, M., and Cook. C. $J$.: the effect of thyroxine on the maturation of fetal rabbit lung. Biol. Neonat.. 22: 161 (1973).

32. Requests for reprints should be addressed to: Dr. Akhtar Mahmood. Department of Biochemistry, Postgraduate Institute of Medical Education and Research. Chandigarh-160012. India.

33. Received for publication January 30,1980

34. Accepted for publication June 6. 1980. 